\section{Commentary: To see the "STARS," we must look up (from the incision)}

\author{
Kevin P. Landolfo, MD, MSc
}

Dr James Cox published the first series of "Cox-maze" procedures for the surgical treatment of atrial fibrillation (AF) in $1991 .^{1}$ Several modifications to the original lesion set have been subsequently introduced as well as the application of different energy sources to facilitate the contemporary procedure beyond the "cut-and-sew" approach. ${ }^{2-4}$ The now well-established surgical treatment for AF includes less-invasive, beating-heart, and hybrid approaches. ${ }^{5,6}$ In the current issue of the Journal, Badhwar ${ }^{7}$ describes a robotic-assisted, biatrial approach for the surgical treatment of AF as either a stand-alone procedure or with concomitant surgery. The manuscript describes his preferred approach (since 2016), used in more than 150 patients, detailing the technical aspects of the operation as presented virtually at the American Association for Thoracic Surgery STARS (Surgical Treatment for Arrhythmias and Rhythm Disorders) meeting in 2020.

His approach involves the use of the Da Vinci Xi robotic system, peripheral cannulation for cardiopulmonary bypass, and a biatrial approach for AF ablation following cardioplegic arrest. Robotic atriotomies are performed followed by cryoprobe lesion sets in both the right and left atria using solely cryothermic energy. A roboticassisted 2-layer suture closure ligates the left atrial appendage in all cases. The accompanying images and video demonstrate the exceptional fidelity of the robotic visualization and the details of the technique (highly recommended).

The success of less-invasive surgical approaches is predicated on 3 important principles. First, these approaches

\footnotetext{
From the Mayo Clinic Alix School of Medicine, and Department of Cardiothoracic Surgery, Mayo Clinic, Jacksonville, Fla.

Disclosures: The author reported no conflicts of interest.

The Journal policy requires editors and reviewers to disclose conflicts of interest and to decline handling or reviewing manuscripts for which they may have a conflict of interest. The editors and reviewers of this article have no conflicts of interest.

Received for publication Oct 8, 2021; revisions received Oct 8, 2021; accepted for publication Oct 8, 2021; available ahead of print Oct 13, 2021.

Address for reprints: Kevin P. Landolfo, MD, MSc, Mayo Clinic, 4500 San Pablo Rd,

Jacksonville, FL 32224 (E-mail: Landolfo.kevin@mayo.edu).

J Thorac Cardiovasc Surg 2023;165:113-4

$0022-5223 / \$ 36.00$

Copyright (c) 2021 by The American Association for Thoracic Surgery

https://doi.org/10.1016/j.jtcvs.2021.10.013
}

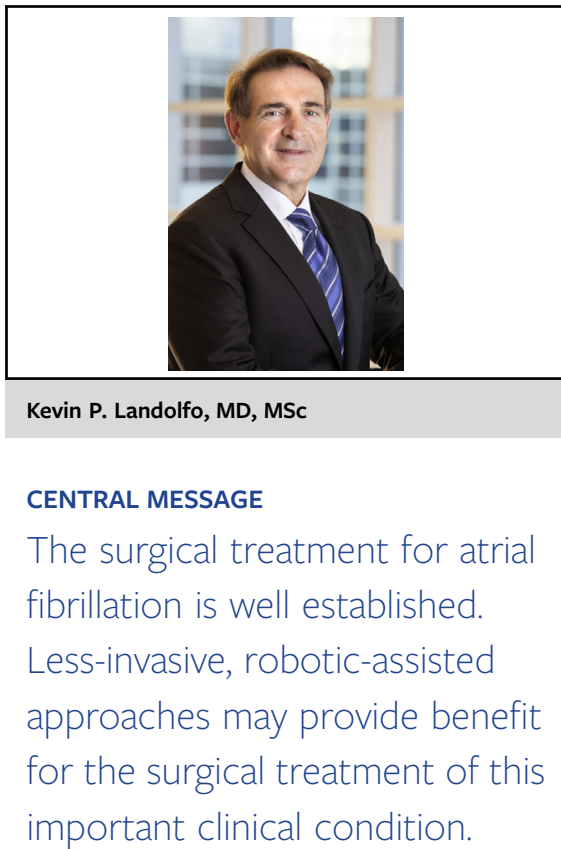

should not jeopardize patient safety. Second, the operation should conform to best surgical practice. Using their approach, the author and his team demonstrate steadfast adherence to the proven Cox-maze lesion set. Third, a benefit in cosmesis and more rapid recovery should be demonstrated. Overall, while the current manuscript is a solely technical description, Dr Badhwar is to be congratulated on the application of a less-invasive robotic platform to $\mathrm{AF}$ ablation and adherence to the proven effectiveness of the Cox-maze lesion set.

How is this technical report of robotic ablation placed in context of AF surgery overall? Despite the proven success of the Cox-maze IV procedure, widespread surgical adoption has been slow, even with concomitant open cardiac surgical procedures. ${ }^{8} 9$ The explanation for this may be a perception of increased risk of the Cox-maze surgical procedure or the underappreciation of the clinical importance of AF. The Journal continues to stress the significance of $\mathrm{AF}$, as evidenced by numerous previous publications evaluating surgical treatments. ${ }^{3,8,10}$ Notably, the Journal published the "AATS Expert Consensus Guidelines: Examining Surgical Ablation for Atrial Fibrillation" in 2017. ${ }^{10}$ These guidelines examine the safety and efficacy of surgical treatment of AF, providing strong evidence for broad application of the procedure. While not all cardiac surgeons are likely to perform robotic ablation for AF, the current technical description adds to the literature regarding effective surgical ablation of AF. Perhaps a look up to the "STARS" 
will allow us to refocus on the surgical treatment of this important clinical condition.

\section{References}

1. Cox JL, Boineau JP, Schuessler RB, Ferguson TB, Cain ME, Lindsay BD. Successful surgical treatment of atrial fibrillation. Review and clinical update. JAMA. 1991;266:1976-80.

2. Patwardian AM, Dave HH, Tamhane AA, Pandit SP, Dalvi BV, Golam K. Intraoperative radiofrequency micropolar coagulation to replace incisions of the maze III procedure for correcting atrial fibrillation in patients with rheumatic valvular disease. Eur J Cardiothorac Surg. 1997;12:627-33.

3. Gynor SL, Diodato MD, Prasad SH, Ishii Y, Schuessler RB. A prospective singlecenter clinical trial of a modified Cox-maze procedure with bipolar radio frequency ablation. J Thorac Cardiovasc Surg. 2004;128:535-42.

4. Mokadem NA, McCarthy PM, Gillinov AM, Ryan WH, Moon MR, Mack MJ. A prospective multicenter trial of bipolar radiofrequency ablation for atrial fibrillation early results. Ann Thorac Surg. 2004;78:1665-70.
5. Pison L, La Meir M, van Opstal J, Blaauw Y, Maessen J. Hybrid thoracoscopic surgical and transvenous catheter ablation of atrial fibrillation. J Am Coll Cardiol. 2021;60:54-61.

6. Edgerton Z, Perini AP, Horton R, Trivedi C, Santangeli P, Bai R. Hybrid procedure (endo/epicardial) versus standard ablation of long-standing persistent atrial fibrillation: results from a single center. J Cardiovasc Electrophysiol. 2016;27: 524-30.

7. Badhwar V. Robotic-assisted biatrial Cox-maze ablation for atrial fibrillation. J Thorac Cardiovasc Surg. 2023;165:108-12.

8. Malaisrie SC, McCarthy PM, Kruse J, Matsoiuka RA, Churyla A, GrauSepulveda MV, et al. Ablation of atrial fibrillation during coronary artery bypass grafting: late outcomes in a Medicare population. J Thorac Cardiovasc Surg. 2021;161:1251-61.

9. Lawrence CP, Henn MC, Damiano RJ Jr. Surgical ablation for atrial fibrillation: techniques, indications, and results. Curr Opin Cardiol. 2015;30:58-64.

10. Ad N, Damiano RJ Jr, Badhwar V, Calkins H, La Meir M, Nitta T, et al. Expert consensus guidelines: examining surgical ablation for atrial fibrillation. J Thorac Cardiovasc Surg. 2017;153:1330-54. 